\title{
PENGEMBANGAN PERTANIAN TERPADU DI DESA TIDU KECAMATAN BUKATEJA KABUPATEN PURBALINGGA
}

\section{INTEGRATED AGRICULTURAL DEVELOPMENT IN VILLAGE TIDU DISTRICT BUKATEJA}

\author{
${ }^{1)}$ Ambar Pujiyatno, ${ }^{2)}$ Muchammad Agung Miftahuddin \\ ${ }^{1)}$ Program Studi Sastra, Fakultas Sastra, Universitas Muhammadiyah Purwokerto, \\ 2) Program Studi Manajemen, Fakultas Ekonomi, Universitas Muhammadiyah Purwokerto \\ Jl. Raya Dukuh Waluh PO BOX 202 Purwokerto 53182 \\ ${ }^{1)}$ barjiyat@yahoo.co.id
}

\begin{abstract}
ABSTRAK
Kegiatan bertujuan meningkatkan kemampuan dan ketrampilan anggota kelompok tani dalam mengembangkan pertanian terpadu dengan cara meningkatkan kemampuan dan ketrampilan para anggotanya dalam hal penguasaan teknologi budidaya tanaman pangan, peternakan, dan perikanan secara terpadu, serta kemampuan berwirausaha. Tujuan adalah terbentuknya desa Tidu sebagai pusat pengembangan pertanian terpadu. Berdasarkan permasalahan yang ada, perlu dilakukan usaha pembinaan berkesinambungan. Metode yang digunakan adalah pelatihan dan alih teknologi pertanian terpadu dengan melibatkan mahasiswa peserta KKN-PPM untuk melakukan kegiatan pendampingan dan pembinaan.Pelatihan dilakukan dengan perkuliahan klasikal dan alih teknologi dengan praktik langsung. penyampaian materi dilakukan dengan metode ceramah, diskusi, dan simulasi. Praktik langsung budidaya tanaman pangan, budidaya ternak, dan budidaya ikan lele mulai dari persiapan, pengolahan hasil, teknik pengemasan dan perijinan. Pendampingan dilakukan selama pelatihan dan alih teknologi, Pembinaan dilakukan dengan membimbing dan memantau anggota kelompok tani setelah kegiatan pelatihan selesai, pembinaan dilakukan secara rutin setiap dua minggu atau sesuai permintaan mitra atau Tim KKN-PPM. Kemitraan diwujudkan dengan memberi bantuan modal dan teknis. Bantuan modal berupa sarana dan prasarana pertanian terpadu. Bantuan teknis berupa peningkatan kemampuan dan ketrampilan pertanian terpadu.
\end{abstract}

Kata Kunci : kelompok tani, pemberdayaan, dan pendampingan

\begin{abstract}
Activities aimed at improving the capabilities and skills of members of farmers in developing integrated farming by improving the capabilities and skills of its members in terms of technological mastery on cultivation of food crops, livestock and fisheries in an integrated manner, as well as entrepreneurship skills. It is to make Tidu as the center of an integrated agricultural development. The method used is the training and integrated agricultural technology transfer.Training is done with classical lectures and technology transfer to the practice. Delivery of material is done by lectures, discussions, and simulations. Practice of food crop cultivation, animal breeding, and cultivation of catfish ranging from the preparation, processing, packaging and licensing techniques.Assistance was done during training and technology transfer, coaching is done by guiding and monitoring the members of farmers after the training is completed, the coaching is done routinely. Partnership is realized by providing capital and assistance. Assistance is integrated agricultural infrastructure. Technical assistance is increased capacity and integrated farming skills.
\end{abstract}

Keywords : farmer groups, cultivation, assistance, and coaching

Submited : 5 Desember 2016 Revision : 20 Desember 2016 Accepted : 21 Januari 2017 


\section{PENDAHULUAN}

Desa Tidu merupakan salah satu dari 14 desa yang ada di kecamatan Bukateja kabupaten Purbalingga, memiliki luas wilayah 153,2045 ha, jumlah penduduk 3.028 orang yang terdiri atas 1.532 lelaki dan 1.496 perempuan. Sebagian besar penduduk bermatapencaharian sebagai petani, buruh tani, pedagang, tukang, buruh bangunan, sektor jasa, PNS/TNI/POLRI, pekerjaan lain nya. Jumlah penduduk usia produktif ( $15-$ 55 tahun) sekitar 1.541 orang, yang bekerja sebagai buruh tani dan tidak mempunyai pekerjaan tetap masing-masing 121 dan 361 orang. Jumlah rumah tangga miskin yang menerima bantuan pemerintah berupa beras miskin sebanyak (raskin) 377 orang dan bantuan langsung tunai (BLT) sebanyak 377 orang, program keluarga harapan $(\mathrm{PKH})$ sebanyak 89 orang, dan bantuan keluarga miskin (Gakin) sebanyak 29 orang (Monografi Desa Tidu, 2015), data di atas menggambarkan bahwa desa Tidu merupakan desa yang rawan kemiskinan. Desa Tidu terbagi ke dalam tiga RW dan $11 \mathrm{RT}$ dengan perincian RW 1 (terdiri atas 4 RT), RW 2 (terdiri atas 4 RT), dan RW 3 (terdiri atas 3) RT. Selain itu desa Tidu juga terbagi atas tiga dusun, yaitu Dusun Antap, Tidu, dan Tuk Putih.

Desa Tidu memiliki lahan sawah 84,55 ha dan pekarangan 58,73 ha, topografi datar, ketinggian sekitar $90 \mathrm{mdl}$, diapit oleh dua sungai besar, yaitu sungai Klawing dan Serayu, namun sumber air irigasi desa Tidu berasal dari saluran irigasi tersier dari waduk Panglima Besar Soedirman (Mrica) di kabupaten Banjarnegara, sehingga ketersediaan air cukup melimpah dan tersedia sepanjang tahun. Potensi desa yang demikian mampu memacu berkembangnya agribisnis pertanian termasuk di dalamnya sub sektor tanaman pangan dan hortikultura, perikanan dan peternakan. Komoditas tanaman pangan dan hortikultura yang banyak diusahakan oleh petani adalah padi, palawija, sayuran, dan umbi-umbian dalam sistem pertanaman monokultur maupun tumpangsari. Komoditas utama peternakan meliputi sapi, kerbau, kambing (domba), dan ayam, sedangkan komoditas utama perikanan meliputi ikan gurameh, lele, tawes, mujaer, bawal, melem dan nila.

Usaha budidaya tanaman pangan berkembang dengan pesat dan telah menjadi andalan sebagian besar warga desa Tidu karena ketersedian air yang melimpah, mampu memenuhi kebutuhan pangan dan gizi keluarga, mampu memberikan pengasilan untuk memenuhi kebutuhan hidup sehari-hari, dan telah ditekuni bertahun tahun secara turun temurun. Kesulitan petani pembudidaya tanaman pangan adalah kelangkaan dan mahalnya harga pupuk kimia (Urea, ZA, SP 36 dan $\mathrm{K} \mathrm{Cl}$ ) khususnya menjelang dan saat musim tanam. Kelangkaan pupuk dapat menurunnya produksi tanaman pangan, sedangkan mahalnya pupuk meningkatkan biaya produksi. Kelangkaan dan mahalnya harga pupuk kimia pada gilirannya menurunkan pendapatan dan daya beli warga.

Usaha peternakan yang banyak diminati warga desa Tidu adalah peternakan sapi potong, kambing dan ayam buras, hal ini dikarenakan terdapatnya sumber hijauan pakan ternak yang melimpah. Walaupun masih bersekala kecil, namun usaha peternakan sapi potong, kambing dan ayam buras mampu meningkatkan pendapatan keluarga dan pemenuhan gizi, khususnya protein hewani, selain itu usaha peternakan juga berfungsi sebagai tabungan (cadangan) guna memenuhi kebutuhan keuangan yang mendesak, terutama biaya pendidikan anak. Survei pendahuluan oleh tim pelaksanan pengabdian menunjukkan bahwa terdapat sekitar 12 orang peternak sapi potong dan 25 orang peternak kambing, data tersebut menunjukkan bahwa sektor peternakan sapi potong dan kambing telah menjadi tumpuan hidup sebagian warga. Selain itu hampir semua 
warga desa Tidu (95\%) memelihara ayam buras, walapun belum dipelihara secara intensif namun usaha pemeliharaan ayam buras sangat membantu ekonomi warga karena bisa sewaktu-waktu dijual untuk memenuhi kebutuhan hidup.

Usaha perikanan khususnya budidaya ikan lele di desa Tidu juga banyak diminati warga sehingga berkembang dengan pesat dikarenakan mampu menghasilkan uang setiap bulan. Kegiatan budidaya ikan lele menjadi andalan sebagian warga desa Tidu dalam mengatasi kesulitan ekonomi yang mendesak dan pemenuhan kebutuhan gizi keluarga.

Mengingat peran dan kontribusi usaha budidaya tanaman pangan, usaha ternak sapi potong, kambing, ayam buras dan usaha budidaya ikan lele bagi warga desa Tidu sangat besar khusunya dalam meningkatkan kesejahteraan dan pemenuhan gizi dan pangan, maka optimalisasi peran dan fungsi kelompok tani harus ditingkatkan. Ada tiga kelompok tani dan satu Kelompok Wanita Tani (KWT) di desa Tidu, yaitu Maju Makmur, Santosa, Rahayu, dan KWT Melati. Kegiatan utama kelompok tani adalah pertemuan bulanan, arisan, menghimpun dana, melaksanakan program Pemerintah Kabupaten (Pemkab) Purbalingga, pembinaan oleh instansi terkait, dan pertukaran informasi antar anggota, sedangkan kegiatan KWT Melati meliputi pertemuan rutin, kegiatan produktif pembuatan olahan pangan dan budidaya melati gambir di lahan tidur. Keberadaan KWT Melati memiliki peran penting dalam meningkatkan ekonomi keluarga.

Masih rendahnya produksi tanaman pangan, sapi potong, kambing, ayam buras dan ikan lele serta banyaknya wanita yang bekerja sebagai ibu rumah tangga di Desa Tidu, merupakan peluang untuk mengembangkan pertanian terpadu dalam upaya pemberdayaan wanita dan meningkatkan pendapatan serta kesejahteraan keluarga petani. Keterlibatan wanita tani di pedesaan dalam kegiatan ekonomi produktif dipengaruhi oleh faktor ekonomi, yaitu tidak tercukupinya kebutuhan rumah tangga mereka. Sebagai ibu rumah tangga, biasanya wanita yang bertanggung jawab dalam mengatur rumah tangga, baik menyangkut kesehatan gizi keluarga, pendidikan anak, dan pengaturan keuangan keluarga (Elizabeth, 2007). Ketika kebutuhan-kebutuhan tersebut tidak tercukupi, maka wanita yang pertama merasakan dampaknya, sehingga dengan keterlibatan wanita dalam kegiatan ekonomi produktif, setidaknya mampu membantu memenuhi sebagian kebutuhan hidup keluarganya, (Bachrein, $d k k$., 2000).

Keberhasilan pembangunan sektor pertanian termasuk di dalamnya sub sektor peternakan dan perikanan di Kabupaten Purbalingga mestinya mampu meningkatkan kualitas hidup para petani, peternak dan pembudidaya ikan yang telah berhasil meningkatkan produk pertanian, peternakan dan perikanan dari tahun ke tahun, akan tetapi peningkatan tersebut tidak selalu diikuti dengan peningkatan kesejahteraan petani, peternak dan pembudidaya ikan secara merata, sebagian besar petani, peternak dan pembudidaya ikan berskala kecil masih hidup di bawah garis kemiskinan. Informasi dari Dinas Pertanian Tanaman Pangan, Kehutanan dan Perkebunan (Dinpertanhutbun) dan Dinas Peternakan dan Perikanan (Dinnakkan) Kabupaten Purbalingga menyebutkan bahwa upaya meningkatkan kualitas hidup petani, peternak dan pembudidaya ikan berskala kecil terus dilakukan, antara lain melalui kegiatan bantuan penguatan modal, pembinaan teknis budidaya, penguatan ketrampilan budidaya, program pemberian bantuan sarana produksi, seperti pemberian bantuan bibit dan bantuan pakan.

Akhir-akhir ini terjadi penurunan peran dan aktivitas kelompok tani dan KWT dalam upaya meningkatkan produksi pertanian, peternakan dan perikanan oleh 
karena itu diperlukan upaya untuk meningkatkan peran dan aktivitas kelompok tani dan KWT sehingga usaha peningkatan produksi pertanian, peternakan dan perikanan dapat tercapai guna peningkatan pendapatan dan pemenuhan gizi keluarga yang lebih baik. Peningkatan peran kelompok tani dan KWT dapat dilakukan dengan pemberdayaan kelembagaan melalui pembinaan dan pendampingan terus menerus dan berkesinambungan.

Ada beberapa permasalahan yang dihadapi dalam kegiatan pertanian terpadu di desa Tidu, yaitu:

1. Kelangkaan dan mahalnya harga pupuk kimia, hal ini dikarenakan para petani belum mampu menyediakan dan membuat pupuk organik (pupuk kompos padat dan cair) sendiri. Ketidakmampuan ini karena para petani belum menguasai teknologi pembuatan pupuk organik dengan memanfaatkan potensi yang dimiliki desa Tidu.

2. Produksi tanaman pangan masih tergolong rendah, hal ini disebabkan oleh teknologi budidaya tanaman yang diterapkan masih konvensional, terutama dalam manajemen pemberian pupuk, pengendalian hama dan penyakit tanaman, serta penanganan pasca panen.

3. Produksi ternak yang dihasilkan masih tergolong rendah, hal ini disebabkan oleh teknologi budidaya sapi potong, kambing dan ayam buras masih konvensional khususnya dalam penerapan teknologi pakan ternak, teknologi reproduksi tenak, pencegahan dan pemberantasan penyakit ternak.

4. Produksi ikan lele yang dihasilkan juga masih rendah, hal ini disebabkan karena penguasaan teknologi budidaya ikan lele masih rendah terutama dalam manajemen pengadaan bibit bermutu, pemberian pakan, pengelolaan kualitas air, serta pengendalian hama dan penyakit ikan.

5. Pendapatan dari hasil budidaya tanaman pangan, budidaya sapi potong, kambing, ayam buras dan ikan lele masih rendah. Hal ini disebabkan biaya produksi tinggi khususnya biaya pupuk, pakan ternak dan pakan ikan. Selama ini petani menggunakan pupuk, konsentrat pakan ternak, dan pakan ikan lele buatan pabrik yang harganya sangat tinggi sehingga mengurangi keuntungan yang diperoleh

6. Variasi produk olahan hasil ternak dan ikan lele masih rendah dan belum dikemas dengan baik dan menarik. Hal ini disebabkan penguasaan teknologi pengolahan hasil ternak dan ikan lele masih rendah, teknologi pengemasan produk olahan hasil ternak dan ikan lele belum baik dan menarik sehingga produk olahannya kurang diminati pasar dan tidak tahan lama disimpan.

Permasalahan yang lebih mengkhawatirkan adalah menurunnya minat generasi muda terhadap usaha pertanian, peternakan dan perikanan. Desa Tidu termasuk desa yang mengalami krisis kekurangan tenaga kerja usia muda. Pelaku usaha pertanian, peternakan dan perikanan saat ini masih didominasi oleh warga berusia tua (lanjut). Generasi muda desa Tidu lulusan SD, SLTP, maupun SLTA lebih senang merantau ke kota untuk mencari pekerjaan. Hal ini dikarenakan usaha sektor pertanian, peternakan dan perikanan belum memberikan jaminan masa depan. Jika hal ini berlangsung terus, suatu ketika desa Tidu akan kehilangan generasi muda yang menekuni usaha pertanian, peternakan dan perikanan. Hal ini dapat mengancam keberlanjutan usaha pertanian, peternakan dan perikanan di desa Tidu, sehingga pada akhirnya menyebabkan terbengkalainya lahan pertanian, peternakan dan perikanan. 
Selain itu, permasalahan kultur petani yang melekat dalam kegiatan sektor peritanian adalah tingkat pengetahuan dan ketrampilan yang rendah, wawasan yang sempit, dan kurang memiliki motivasi untuk lebih berkembang dan menjadi lebih maju.

Sektor pertanian, termasuk sub sektor peternakan dan perikanan di Kabupaten Purbalingga mampu bertahan dan menjadi penopang perekonomian daerah, walaupun saat ini banyak mengalami kendala yang serius, khususnya dalam penyediaan bibit bermutu, teknologi budidaya dan pemeliharaan, penyediaan pakan, pengolahan hasil, dan pemasaran produk olahan. Usaha mengembangkan sektor pertanian termasuk sub sektor peternakan dan perikanan dipandang sangat tepat mengingat sektor tersebut mampu menjadi penggerak perekonomian masyarakat. Dalam pelaksaannya, kegiatan KKN-PPM ini bermitra dengan Dispertanhubun dan Dinnakan Kabupaten Purbalingga karena kegiatan KKN-PPM sejalan dengan program kerja tahunan kedua dinas tersebut.

Kegiatan KKN-PPM melibatkan seluruh kelompok tani dan KWT desa Tidu sebagai mitra sasaran kegiatan. Kelompok tani dan KWT mendapatkan informasi dan teknologi yang aplikatif sehingga potensi produksi tanaman pangan, sapi, kambing, ayam dan ikan lele serta produk olahannya dapat ditingkatkan dan didayagunakan. Pendayagunaan potensi produksi dilakukan melalui intensifikasi budidaya sedangakan pendayagunaan potensi produk olahan dilakukan dengan good manufacturing practicess sehingga dihasilkan produk olahan pangan yang sesuai standar SNI.

Penerapan teknologi pengemasan vaccum packing terhadap produk olahan pangan meningkatkan nilai tambah yang selanjutnya dapat meningkatkan volume pemasaran. Keberhasilan penerapan teknologi ini diharapkan dapat membantu pemerintah dalam upaya meningkatkan konsumsi daging dan ikan perkapita masyarakat, meningkatkan ketersediaan bahan pangan berprotein hewani yang terjangkau, sehingga pada akhirnya berdampak terhadap peningkatan kualitas hidup masyarakat.

Pengemasan produk olahan pangan yang menarik dengan plastik yang dilengkapi ijin Pangan Industri Perusahaan Rumah Tangga (PIRT) dari Dinas Kesehatan kabupaten Purbalingga memungkinkan kelompok tani dan KWT memasarkan produk olahan pangan dengan daya saing dan daya jual yang lebih tinggi sehingga dapat meningkatkan pendapatannya. Selain itu, produk olahan pangan dapat dijadikan sebagai produk unggulan Kabupaten Purbalingga untuk oleh-oleh para wisatawan yang berkunjung ke Purbalingga.

Berdasarkan uraian di atas, kegiatan KKN PPM ini mengembangkan pertanian terpadu secara terintegrasi mulai dari penyediaan pupuk organik, benih bermutu, teknik budidaya tanaman pangan, sapi potong, kambing, ayam buras dan lele, dan pengolahan hasil, melalui kegiatan penyuluhan, pelatihan, dan pembuatan demplot pertanian terpadu.

Teknologi pertanian terpadu dimulai dari penyediaan pupuk organik melalui pembuatan pupuk kompos fermentasi berbahan dasar kotoran ternak, penyediaan benih tanaman melalui pengadaan benih bersertifikat dan seleksi benih, teknik budidaya tanaman pangan melalui teknologi pemupukan seimbang dengan prinsip tiga $\mathrm{T}$ yaitu tepat jenis, tepat dosis dan tepat waktu, sedangkan pengendalian hama dan penyakit tanaman menggunakan teknologi pengendalian hama dan penyakit terpadu. 
Penyediaan bibit ternak bermutu melalui teknologi seleksi bibit, penyediaan pakan dengan teknologi pembuatan pakan murah berbasis bahan lokal, pengolahan hasil ternak dilakukan dengan mengembangkan aneka produk olahan ternak yang memenuhi SNI, pengemasan produk olahan ternak menggunakan vacuum packing.

Pembenihan ikan lele menggunakan teknologi pemijahan buatan (induce breeding), teknologi pembesaran ikan menggunakan sistem resirkulasi, teknologi pembuatan pakan ikan murah menggunakan bahan-bahan lokal, teknologi pengolahan anaka produk olahan lele yang memenuhi SNI.

Kerjasama antara Universitas Muhammadiyah Purwokerto (UMP), Pemkab Purbalingga, serta kelompok mitra melalui program pemberdayaan masyarakat diyakini berhasil dalam mengembangkan pertanian terpadu di desa Tidu guna menunjang kemandirian pangan. UMP menyediakan pakar yang kompeten di bidangnya serta melibatkan mahasiswa dari berbagai disiplin ilmu untuk mencapai sasaran dan keluaran yang strategis. Pemkab Purbalingga menyediakan dana pendamping, serta kelompok tani mitra mengikuti setiap tahap pembinaan dengan serius dan menyebarluaskan teknologi pertanian terpadu kepada warga lainnya. Kerjasama yang baik antara Perguruan Tinggi, Pemkab Purbalingga dan mitra diharapkan mampu meningkatkan nilai ekonomis produk pertanian, peternakan dan perikanan serta berperan dalam pemberdayaan masyarakat guna meningkatkan kesejahteraan. Program ini dapat menjadi landasan untuk menjalin kemitraan dengan pebisnis olahan produk pertanian, peternakan dan perikanan. Memanfaatkan hasil penelitian, kerjasama dengan Pemkab Purbalingga dan sektor industri, di harapkan program ini mampu meningkatkan volume penjualan aneka olahan produk pertanian, peternakan dan perikanan melalaui perluasan jaringan pemasaran hingga ke seluruh wilayah di Indonesia bahkan dunia melalui media internet.

Metode yang dikembangkan dalam pemberdayaan mitra adalah peningkatan pengetahuan dan ketrampilan pengurus dan anggota kelompok tani dan KWT desa Tidu melalui alih teknologi dan praktik langsung pembuatan demplot (percontohan) pertanian terpadu dengan melibatkan mahasiswa KKN yang didampingi oleh dosen pembimbing lapangan. Pemberdayaan kelompok tani diarahkan pada upaya pengembangan pertanian terpadu berbasis tanaman pangan yang dipadukan dengan usaha budidaya ternak sapi potong dan ikan lele. Sedangkan pemberdayaan KWT difokuskan pada usaha pengolahan hasil ternak sapi potong dan ikan lele, dengan cara ini mitra dapat secara langsung berdiskusi dan melihat contoh hasil kegiatan. Bidang kegiatan meliputi lingkungan, pertanian, peternakan, perikanan dan sosial-ekonomi. Kegiatan dilanjutkan dengan penelitian guna menyempurnakan penelitian sebelumnya, kegiatan ini juga diharapkan menjadi embrio dalam mengembangkan Desa Tidu menjadi wilayah pertanian terpadu dan mandiri.

Tujuan atau target kegiatan KKNPPM adalah :

a) Meningkatkan kepedulian dan empati mahasiswa terhadap permasalahan masyarakat, terutama permasalah pengembangan pertanian terpadu,

b) Mengatasi kelangkaan pupuk dengan cara menyediakan dan membuat pupuk organik (pupuk kompos padat dan cair) sendiri.

c) Mengatasi permasalahan rendahnya produksi tanaman pangan dengan menerapkan teknik budidaya yang 
baik, khususnya manajemen pemberian pupuk, pengendalian hama dan penyakit tanaman, serta penanganan pasca panen,

d) Mengatasi permasalahan rendahnya produksi ternak (sapi potong, kambing dan ayam buras) dengan penekanan pada perbaikan penerapan teknologi pakan ternak, teknologi reproduksi tenak, pencegahan dan pemberantasan penyakit ternak,

e) Mengatasi permasalahan rendahnya produksi ikan lele melalui perbaikan pengadaan bibit bermutu, pemberian pakan, pengelolaan kualitas air, serta pengendalian hama dan penyakit ikan,

f) Mengatasi permasalahan rendahnya pendapatan petani dari sektor tanaman pangan, sapi potong, kambing, ayam buras dan ikan lele dilakukan melalui penyediaan pakan murah.

g) Mengatasi permasalahan terbatasnya produk olahan hasil ternak dan ikan lele, dengan meningkatkan variasi produk olahan dan perbaikan teknik pengemasan.

\section{METODE}

Metode pelaksanaan kegiatan KKN PPM meliputi:

1. Persiapan dan Pembekalan

a. Perekrutan mahasiswa peserta $\mathrm{KKN}$ PPM : 1) Persyaratan mahasiswa peserta KKN-PPM adalah telah menempuh 110 SKS dengan IPK minimal 2.00. 2) Mahasiswa peserta KKN-PPM berasal dari Program Studi (PS) yang sesuai dengan tema kegiatan, terdiri atas 10 Program Studi yaitu Agroteknologi (3 mahasiswa), Agrobisnis (3 mahasiswa), Teknik Kimia (3 mahasiswa), Teknik Informatika (4 mahasiswa), Psikologi (2 mahasiswa), Ilmu Hukum (2 mahasiswa), Akutansi (4 mahasiswa), Manajemen (4 mahasiswa), Farmasi (3 mahasiswa), dan Keperawatan (2 mahasiswa), jumlah mahasiswa yang dibutuhkan 30 mahasiswa. 3) Mahasiswa calon peserta KKN-PPM harus bersedia mengikuti seleksi yang dilaksanakan oleh panitia KKN. 4) Penentuan DPL berdasarkan bidang ilmu yang sesuai dengan tema kegiatan dan pengalaman pelaksanaan Tridharma, dengan ketentuan satu orang membimbing 30 mahasiswa, sehingga dibutuhkan satu orang DPL.

b. Pembekalan Mahasiswa KKN- PPM Materi proses dan materi isi, sebagai berikut : 1) Materi proses adalah materi yan dibekalkan kepada mahasiswa sebelum melaksanakan KKN-PPM agar mahasiswa siap melakukan KKN-PPM (falsafah KKN$\mathrm{PPM}$ ), berisi penyusunan program KKN-PPM secara parsitipatif, pelaporan, penilaian, dan tata tertib. Pembekalan materi proses diberikan oleh LPPM UMP, Dinas terkait, dan praktisi. 2) Materi isi adalah materi yang bersifat teknis lapangan yang dibekalkan kepada mahasiswa untuk diaplikasikan di lapangan sesuai dengan tema/judul KKN-PPM. 3) Seluruh mahasiswa peserta KKN-PPM mendapatkan pembekalan materi isi yang sama, namun tanggung jawab setiap materi selama menjalankan program KKN-PPM dikelompokkan sesuai dengan rumpun ilmu. Pemateri pembekalan adalah dosen UMP yang sesuai dengan bidang keahlianya, penanggung jawab dan DPL KKNPPM, serta praktisi. Pembekalan meliputi pemberian materi klasikal dan praktek laboratorium di program studi terkait di lingkungan UMP.

\section{c. Pelaksanaan}

Upaya pencapaian tujuan ditempuh melalui serangkaian kegiatan yang dilaksanakan secara sistematis berurutan dan berkesinambungan. Upaya ini diwujudkan dalam penerapan teknologi pada khalayak sasaran. Metode yang digunakan dalam melaksanakan penerapan 
teknologi kepada khalayak sasaran adalah partisipasi aktif dari khalayak sasaran mitra untuk berperan aktif dalam kegiatan dan didampingi oleh tim penerapan teknologi (dari perguruan tinggi baik dosen maupun mahasiswa). Tahap pelaksanaan kegiatan meliputi persiapan khalayak sasaran, persiapan materi, penentapan jadwal kegiatan dan pelaksanaan kegiatan.

Persiapan khalayak sasaran diawali dengan seleksi khalayak sasaran strategis, yaitu pengurus dan anggota kelompok tani dan KWT yang memiliki kemauan dan kemampuan melaksanakan seluruh kegiatan, penetapan waktu ceramah, diskusi, pembuatan demplot, bimbingan dan monitoring.

Persiapan materi pelatihan, bahan-bahan dan peralatan praktek pembuatan demplot dipersiapkan seminggu sebelumnya. Cara penyampaian materi melalui ceramah klasikal, diskusi, pemutaran VCD, dan penayangan gambar animasi mengenai teknologi pertanian terpadu sehingga mempermudah mitra dalam memahami materi yang disampaikan.

Penetapan jadwal pemberi ceramah dan praktek pembuatan demplot dilakukan bersama antara tim pelaksana KKN-PPM dan khalayak sasaran strategis.

\section{HASIL DAN PEMBAHASAN}

\section{Pelatihan Teknologi Budidaya Tanaman Pangan}

Sesuai jadwal yang disepakati maka telah dilaksanakan kegiatan penyuluhan budidaya tanaman pangan dengan metode ceramah klasikal dan diskusi. Kegitan dilanjutkan dengan pemberian materi oleh tim pelaksana KKN PPM, metode pemberian materi berupa ceramah klasikal dan diskusi. Materi yang diberikan meliputi : Pelatihan pembuatan pupuk organik yang meliputi pembuatan bioaktivator, pembuatan pupuk kompos fermentasi, dan pembuatan pupuk organik cair, pelatihan pengadaan bahan tanam berkualitas, pelatihan manajemen pemberian pupuk, pelatihan pengendalian hama dan penyakit tanaman, serta pelatihan penanganan pasca panen. Pemateri juga memberi kesempatan kepada peserta untuk tanya jawab dan diskusi dengan pemateri maupun sesama peserta. Teknik ini mampu menciptakan suasana pelatihan sehingga permasalahan dan kesulitan dapat dicarikan jalan keluarnya. Mitra kegiatan KKN PPM terlihat sangat antusias dalam mengikuti kegiatan ceramah dan diskusi, hal ini terlihat dari banyaknya pertanyaan yang diajukan oleh peserta/mitra.

Setelah dilaksanakan ceramah dan diskusi teknologi budidaya tanaman pangan, maka dilanjutkan dengan kegiatan praktik pembuatan pupuk organik, yang meliputi praktik pembuatan bioaktivator, pupuk kompos fermentasi dan pupuk organik cair. Praktik pembuatan pupuk organik dilaksanakan pada hari Selasa tanggal 2 Agustus 2016. Hasil pelatihan berupa 10 liter bioaktivator, $1.250 \mathrm{~kg}$ pupuk kompos fermentasi dan 40 liter pupuk organik cair. Bioaktivator yang dihasilkan digunakan untuk pembuatan pupuk kompos fermentasi dan pupuk organik cair (POC). Pupuk kompos fermentasi dan POC digunakan untuk budidaya tanaman jagung.

Praktik budidaya tanaman jagung dilaksanakan pada hari Senin, tanggal 22 Agustus 2016 yang ditempatkan di kelompok tani Maju Makmur dusun Antap seluas 200 ubin $\left(2.800 \mathrm{~m}^{2}\right)$, varietas jagung yang digunakan adalah Pioneer bisi 2, dengan jumlah benih 2 butir per lubang, jenis pupuk yang digunakan adalah pupuk kompos hasil praktik sebelumnya. Hingga akhir pelaksanaan KKN PPM pertanaman jagung terlihat tumbuh subur dan merata, namun belum mencapai umur panen, pemanenan akan dilaksanakan bulan November 2016. Saat ini tanaman jagung 
sudah keluar tongkol jagungnya dan siap dipanen, sehingga belum bisa dilaporkan produksinya. Meskipun demikian, budi daya tanaman jagung bisa dikatakan hampir $100 \%$ berhasil untuk satu siklus tanam, sehingga akan bisa dilanjutkan penanaman jagung tahap berikutnya.

\section{Pelatihan Teknologi Budidaya Ternak}

Pelatihan teknologi budidaya ternak dilakukan dengan cara ceramah dan diskusi klasikal. Pemberian materi secara klasikal dilaksanakan oleh tim pelaksana KKN PPM. Materi yang diberikan meliputi : teknik pembuatan kandang, pembuatan pakan, pemeliharaan ternak, reproduksi ternak, pencegahan dan pemberantasan penyakit ternak (meliputi sapi, kambing, dan ayam). Pemateri juga memberi kesempatan kepada peserta untuk tanya jawab dan diskusi dengan pemateri maupun sesama peserta. Teknik ini mampu menciptakan suasana pelatihan sehingga permasalahan dan kesulitan dapat dicarikan jalan keluarnya. Mitra kegiatan KKN PPM terlihat sangat antusias dalam mengikuti kegiatan ceramah dan diskusi, hal ini terlihat dari banyaknya pertanyaan yang diajukan oleh peserta/mitra.

Setelah dilaksanakan ceramah klasikal dan diskusi teknologi budidaya ternak, maka dilanjutkan dengan kegiatan praktik pembuatan demplot budidaya ternak Sapi. Praktik pembuatan demplot budidaya ternak Sapi dilaksanakan di kelompok tani Maju Makmur (dusun Antap), Tani Santosa (dusun Tidu) dan Tani Rahayu (dusun Tuk Putih) pada hari Ahad, tanggal 7 Agustus 2016. Hasil pelatihan berupa tiga buah kandang sapi yang masing berisi satu ekor sapi usia 10 bulan. Demplot budidaya ternak sapi bertujuan untuk meningkatkan populasi ternak sapi di desa Tidu, juga sebagai sumber pupuk organik untuk budidaya pertanian di desa Tidu.
Hingga akhir pelaksanaan KKN PPM ternak ketiga ekor sapi terpelihara dengan baik, yang ditunjukkan dengan kondisi kesehatan sapi yang baik, tersedia pakan ternak yang cukup, kebersihan kandang sapi terjaga dengan baik, limbah kotoran ternak tertangani dengan baik.

Hasil yang dicapai saat ini adalah pemeliharaan tiga ekor sapi yang semakin besar dan sehat yang berada di tiga dusun tersebut di atas. Sapi hibah yang berada di Dusun 1 (Dusun Antap) dikelola oleh Kelompok Tani "Maju Makmur" dan dipelihara oleh Bapak Nasukha, Dusun 2 (Dusun Tidu) dikelola oleh Kelompok Tani "Tani Santosa" dan dipelihara oleh Bapak Faturrohman, dan Dusun 3 (Dusun Tuk Putih) dikelola oleh Kelompok Tani "Tani Rahayu" dan dipelihara oleh Bapak Yono. Hasil tersebut dapat dicapai karena adanya pendampingan Tim Pelaksana KKN PPM dan koordinasi serta komunikasi yang baik dengan para anggota kelompok tani.

\section{Pelatihan Teknologi Budidaya Ikan \\ Lele}

Pelatihan teknologi budidaya ikan lele diawali dengan ceramah dan diskusi klasikal. Pemberian materi secara klasikal dilaksanakan oleh tim pelaksana KKN PPM. Materi yang diberikan meliputi : teknik penyiapan kolam dan media pembesaran ikan, pemilihan benih ikan dan proses adaptasi penebaran benih ikan, manajemen pemberian pakan ikan, pengendalian penyakit ikan dan pengelolaan kualitas air. Pemateri juga memberi kesempatan kepada peserta untuk tanya jawab dan diskusi dengan pemateri maupun sesama peserta. Teknik ini mampu menciptakan suasana pelatihan sehingga permasalahan dan kesulitan dapat dicarikan jalan keluarnya. Mitra kegiatan KKN PPM terlihat sangat antusias dalam mengikuti kegiatan ceramah dan diskusi, hal ini terlihat dari banyaknya pertanyaan yang diajukan oleh peserta/mitra. Setelah pelatihan teknologi budidaya ikan lele 
selesai dan telah terjadi transfer teknologi, maka dilanjutkan dengan Pembuatan demplot budidaya ikan lele dalam kolam terpal.

Praktik pembuatan demplot budidaya ikan lele dalam kolam terpal dilaksanakan di kelompok tani Maju Makmur (dusun Antap), Tani Santosa (dusun Tidu) dan Tani Rahayu (dusun Tuk Putih) pada hari Senin, tanggal 8 Agustus 2016. Hasil pelatihan berupa tiga kolam terpal ikan lele berukuran 5 x $3 \mathrm{~m}$, setiap kolam terpal berisi 1.500 ekor benih ikan lele berukuran 7-9 cm. Demplot budidaya ikan lele bertujuan menyediaakan bahan baku pembuatan abon, kerupuk dan nugget lele yang dikelola oleh KWT Melati. Kontribusi masyarakat desa Tidu dalam pembuatan demplot budidaya ikan lele sangat besar, hal ini terlihat dari bantuan dana pemdes Tidu dan swadaya masyarakat mampu menghasilkan dua kolam terpal ikan lele yang masing masing berisi 1.500 benih ikan lele berukuran 7-9 $\mathrm{cm}$. Total kolam terpal ikan lele yang dihasilkan sebanyak 5 buah.

Hingga akhir pelaksanaan KKN PPM kolam terpal ikan lele masih terpelihara dengan baik, terlihat dari tingkat kematian benih ikan lele yang sangat rendah, pertumbuhan benih ikan lele seragam, benih ikan lele tumbuh sehat dan aktif bergerak.

Hasil yang dicapai saat ini adalah adanya tiga tempat budi daya ikan lele dengan menggunakan terpal yang semakin besar dan sehat yang berada di tiga dusun tersebut di atas. Ikan lele hibah yang berada di Dusun 1 (Dusun Antap) dikelola oleh Kelompok Tani "Maju Makmur" dan dipelihara oleh Bapak Jirun, Dusun 2 (Dusun Tidu) dikelola oleh Kelompok Tani "Tani Santosa" dan dipelihara oleh Bapak Ali Nurdin, dan Dusun 3 (Dusun Tuk Putih) dikelola oleh Kelompok Tani "Tani Rahayu" dan dipelihara oleh Bapak Slamet. Hasil tersebut dapat dicapai karena adanya pendampingan Tim Pelaksana
KKN PPM dan koordinasi serta komunikasi yang baik dengan para anggota kelompok tani.

\section{Pelatihan Pengolahan Hasil Ternak dan Ikan}

Pelatihan pengolahan hasil ternak dan ikan lele diawali dengan ceramah dan diskusi klasikal. Pemberian materi secara klasikal dilaksanakan oleh tim pelaksana KKN PPM. Materi yang diberikan meliputi : teknik pemilihan bahan baku pembuatan abon, kerupuk, dan nugget, teknik pengolahan produk ternak dan ikan menjadi abon, nugget, dan kerupuk ikan, dan teknik modifikasi pengemasan produk olahan ternak dan ikan. Pemateri juga memberi kesempatan kepada peserta untuk tanya jawab dan diskusi dengan pemateri maupun sesama peserta. Teknik ini mampu menciptakan suasana pelatihan sehingga permasalahan dan kesulitan dapat dicarikan jalan keluarnya. Mitra kegiatan KKN PPM terlihat sangat antusias dalam mengikuti kegiatan ceramah dan diskusi, hal ini terlihat dari banyaknya pertanyaan yang diajukan oleh peserta/mitra. Setelah pelatihan pengolahan hasil ternak dan ikan dan telah terjadi transfer teknologi, maka dilanjutkan dengan Praktek pembuatan abon, kerupuk, dan nugget lele.

Praktik pembuatan abon, kerupuk dan nugget lele dilaksanakan di KWT Melati, praktik pembuatan abon, kerupuk dan nugget lele masing masing mengunakan satu resep $(5 \mathrm{~kg})$, hasil pengolahan hasil berupa abon $(3,5 \mathrm{~kg}$, kerupuk $12,5 \mathrm{~kg}$ dan nugget lele $(15 \mathrm{~kg})$ produks tersebut dipasarkan dikalangan pemdes dan TPPKK desa Tidu. Guna menjaga kelangsungan usaha pengolahan hasil ikan lele berupa abon, kerupuk dan nugget maka Tim pelaksana KKN PPM memberikan bantuan modal peralatan yang terdiri atas Kompor gas, tabung gas, saringan, soled, pisau, talenan, baki, loyang, wajan, dandang dan bahan baku 
pembuatan abon, kerupuk dan nugget lele masing sebanyak 2 resep $(10 \mathrm{~kg})$.

Hasil yang dicapai dari pengolahan ikan lele adalah adanya produk makanan dari ikan lele seperti abon lele (\#AADC), nugget lele, kerupuk lele (Kerupuk Lele Criyik) dan Jahe (J-Loks). Pengolahan produk tersebut dilakukan oleh para anggota Kelompok Wanita Tani "Melati" yang dipimpin oleh Ibu Sudiyati. Keberlangsungan produksi hasil olahan lele disebabkan oleh antusiasnya para anggota KWT, pemberian modal awal untuk produksi, dan pendampingan dan bimbingan oleh Tim Pelaksana KKN PPM, serta adanya koordinasi dan komunikasi yang terjalin dengan baik.

\section{Pelatihan Pengembangan Usaha Pemasaran Hasil Ternak dan Ikan}

Pelatihan pengembangan usaha pemasaran hasil ternak dan ikan dilakukan dengan ceramah dan diskusi klasikal. Pemberian materi secara klasikal dilaksanakan oleh tim pelaksana KKN PPM. Materi yang diberikan meliputi : kewirausahaan, manajemen pemasaran produk olahan ternak dan ikan, pembuatan media promosi dan teknik promosi, analisis usaha ekonomi, pelatihan dan pendampingan periklanan.

Pelatihan dilaksanakan pada hari Ahad, tanggal 21 Agustus 2016, diikuti oleh 15 orang terdiri atas pengurus dan anggota KWT Melati, pengurus dan anggota kelompok tani Maju Makmur, Tani Santosa, Tani Rahayu serta beberap pelaku usaha mikro di desa Tidu.

Pemateri juga memberi kesempatan kepada peserta untuk tanya jawab dan diskusi dengan pemateri maupun sesama peserta. Teknik ini mampu menciptakan suasana pelatihan sehingga permasalahan dan kesulitan dapat dicarikan jalan keluarnya. Para peserta terlihat sangat antusias dalam mengikuti kegiatan ceramah dan diskusi, hal ini terlihat dari banyaknya pertanyaan yang diajukan oleh peserta/mitra.

Luaran kegiatan ini adalah laporan keuangan sederhana dan media promosi. Di akhir kegiatan para peserta pelatihan mampu menghasilkan laporan keuangan sederhana. Laporan keuangan yang berisi catatan sederhana mengenai biaya produksi, biaya penjualan, upah tenaga kerja serta pendapatan dan keuntungan yang diperoleh. Selain itu dihasilkan juga media promosi berupa leaf let sederhana. Hal ini menunjukkan bahwa telah terjadi transfer pengetahuan dan keterampilan kepada peserta

Hasil yang dicapai adalah sekarang usaha produksi hasil olahan lele bisa dikelola dengan baik. Pengelolaan yang bisa dilakukan antaranya perencanaan produksi, pemasaran, dan pelaporan, meskipun pengelolaan yang ditangani masih sederhana, namun demikian bila ditekuni akan berhasil. Produk yang dihasilkan masih skala kecil sehingga cakupan pemasaran juga belum luas dan masih di desa Tidu dan sekitarnya.

\section{Pelatihan Pengembangan Usaha Pertanian Terpadu}

Pelatihan pengembangan usaha pertanian terpadu dilakukan dengan ceramah dan diskusi klasikal. Pemberian materi secara klasikal dilaksanakan oleh tim pelaksana KKN PPM. Materi yang diberikan meliputi : perijinan Depkes, pelabelan dan expired date, Standarisasi produk olahan ternak dan ikan, penjaminan mutu produk olahan ternak dan ikan.

Pelatihan dilaksanakan pada hari Senin, tanggal 15 Agustus 2016, diikuti oleh 8 orang terdiri atas pengurus dan anggota KWT Melati, pengurus dan anggota kelompok tani Maju Makmur, Tani Santosa, Tani Rahayu desa Tidu.

Pemateri juga memberi kesempatan kepada peserta untuk tanya jawab dan 
diskusi dengan pemateri maupun sesama peserta. Teknik ini mampu menciptakan suasana pelatihan sehingga permasalahan dan kesulitan dapat dicarikan jalan keluarnya. Para peserta terlihat sangat antusias dalam mengikuti kegiatan ceramah dan diskusi, hal ini terlihat dari banyaknya pertanyaan yang diajukan oleh peserta/mitra.

Luaran kegiatan ini adalah meningkatnya pengetahuan mitra mengenai proses perijinan industri rumah tangga dan standarisasi produk olahan hasil pertanian, hal ini menunjukkan bahwa telah terjadi transfer pengetahuan dan ketrampilan kepada peserta.

\section{Pelatihan Pengembangan kemitraan dengan Industri}

Pelatihan pengembangan kemitraan dengan industri dilakukan dengan ceramah dan diskusi klasikal serta pelatihan. Pemberian materi secara klasikal dilaksanakan oleh tim pelaksana KKN PPM. Materi yang diberikan meliputi : cara menjalin kerjasama permodalan dan pemasaran dan pendampingan penyusunan proposal. Pelatihan dilaksanakan pada hari Rabu, tanggal 24 Agustus 2016, diikuti oleh 11 orang terdiri atas pengurus dan anggota KWT Melati, pengurus dan anggota kelompok tani Maju Makmur, Tani Santosa, Tani Rahayu desa Tidu.

Pemateri juga memberi kesempatan kepada peserta untuk tanya jawab dan diskusi dengan pemateri maupun sesama peserta. Teknik ini mampu menciptakan suasana pelatihan sehingga permasalahan dan kesulitan dapat dicarikan jalan keluarnya. Para peserta terlihat sangat antusias dalam mengikuti kegiatan ceramah dan diskusi, hal ini terlihat dari banyaknya pertanyaan yang diajukan oleh peserta/mitra.

Pelatihan dan pendampingan dilakukan secara terus menerus sehingga peserta mampu menghasilkan luaran berupa contoh proposal kegiatan. Proposal kegiatan ini merupakan proposal kemitraan dengan dua pihak, yaitu pihak penyedia bahan baku dan pihak pemasaran (toko oleh-oleh) di kabupaten Purbalingga.

\section{Pelatihan Achievement Motivation Training (AMT)}

Pelatihan AMT dilakukan dengan ceramah dan diskusi klasikal, pelatihan dan permainan (game). Pemberian materi secara klasikal dilaksanakan oleh tim pelaksana KKN PPM. Materi yang diberikan meliputi : peningkatan motivasi, berorganisasi, dan bekerjasama.

Pelatihan dilaksanakan pada hari Rabu, tanggal 3 Agustus 2016, diikuti oleh 16 orang terdiri atas pengurus dan anggota KWT Melati, pengurus dan anggota kelompok tani Maju Makmur, Tani Santosa, Tani Rahayu desa Tidu.

Pemateri juga memberi kesempatan kepada peserta untuk tanya jawab, diskusi dan terlibat langsung dalam setiap game yang dilaksanakan.. Teknik ini mampu menciptakan suasana pelatihan yang menyenangkan sehingga para peserta terlihat sangat antusias dan meninkmati training AMT.

Pelatihan dengan game yang dilaksanakan ditujukan agar peserta training memiliki motivasi dalam mengembangkan usahanya serta memiliki kemampuan untuk menghimpun kekuatan yang dimiliki (kelompok tani dan KWT) untuk mencapai tujuan bersama.

Pendampingan dan pembinaan untuk masing-masing program adalah sangat diperlukan. Pendampingan dan pembinaan dilakukan oleh Tim Pelaksana KKN PPM dilakukan sebulan sekali untuk tiap program. Sampai saat ini, masing-masing program sudah mendapatkan pendampingan dan pembinaan sebanyak 
dua kali, yaitu pendampingan dan pembinaan pada pertengahan bulan September dan pertengahan bulan Oktober. Kegiatan pendampingan dan pembinaan dapat digunakan untuk memonitor perkembangan setiap program, mendiskusikan masalah-masalah yang dihadapi atau mencari strategi dan solusi yang baik untuk kemajuan, dan mengevaluasi program-program yang masih berlangsung.

\section{SIMPULAN}

Kesimpulan sementara hasil kegiatan KKN PPM adalah :

1. Terjadi peningkatan kepedulian dan empati mahasiswa terhadap permasalahan masyarakat, terutama permasalah pengembangan pertanian terpadu,

2. Tersedianyan pupuk organi sebagai upaya mengatasi kelangkaan pupuk,

3. Terjadi peningkatan pemahaman masyarakat dalam meningkatkan produksi tanaman pangan dengan menerapkan teknik budidaya yang baik,

4. Meningkatnya pengetahuan dan ketrampilan mitra dalam mengembangkan teknologi pakan ternak, reproduksi tenak, pencegahan dan pemberantasan penyakit ternak, sebagai upaya mengatasi rendahnya produksi ternak,

5. Meningkatnya pengetahuan dan ketrampilan mitra dalam pengadaan bibit lele bermutu, pemberian pakan, pengelolaan kualitas air, serta pengendalian hama dan penyakit ikan lele dalam upaya mengatasi rendahnya produksi ikan lele,

6. Tersedianya alternatif mengatasi rendahnya pendapatan petani dari sektor tanaman pangan, sapi potong dan ikan lele melalui penyediaan pakan murah.

7. Tersedianya variasi produk olahan ternak dan ikan lele serta pengemasannya sebagi alternatif usaha produktif

\section{DAFTAR PUSTAKA}

Bachrein, S., I. Ishaq, dan V.W. Rufaidah. (2000). Peranan Wanita Dalam Pengembangan Usahatani Di Jawa Barat (Studi Kasus: Kecamatan Cikelet, Garut). Jurnal JP2TP 3(1).

Elizabeth, R. (2007). Pengarusutamaan Gender Melalui Managemen Sumberdaya Keluarga Dan Diversifikasi Pendapatan Rumah Tangga Petani Di Pedesaan: Antara Harapan Dan Kenyataan. Makalah, Lokakarya Pengarusutamaan Gender. FEMA IPB Bogor bekerjasama dengan Kementrian Pemberdayaan Perempuan RI 